\title{
Community structure and Distribution of Phytomacrofauna in Iyagbe Lagoon, Southwest, Nigeria ${ }^{* 1}$ ROLAND E. UWADIAE
}

Benthic Ecology Unit, Department of Marine Sciences, University of Lagos Akoka, Lagos, Nigeria

*Corresponding author: eferoland@yahoo.com; ruwadiae@unilag.edu.ng.

\begin{abstract}
This paper reports the results of an investigation into the community structure and spatial distribution of phytomacrofauna inhabiting the roots of water hyacinth in Iyagbe Lagoon Southwest Nigeria. In all, 48 quantitative samples from eight sampling stations collected over a period of six months were analysed. Values obtained for environmental parameters ranged between 3.0 and $3.9 \mathrm{mg} / \mathrm{L}, 1.1$ and $1.7 \mathrm{mg} / \mathrm{L}$, and 40 and $119 \mathrm{~cm}$ for dissolved oxygen, biochemical oxygen demand and transparency respectively. Others were 0.52 - $50.0 \mathrm{mg} / \mathrm{L}$ for total dissolved solid, $0.02-20.10 \mathrm{mg} / \mathrm{L}$ for total suspended solid, and 5.34-8.90 for $\mathrm{pH}$. Three major phytomacrofauna groups; Annelida, Arthropoda and Mollusca were identified from a total of 1,976 individuals of phytomacrofauna collected from the study area. Arthropoda was the most abundant group with a total of 1,500 individuals and accounted for about $76 \%$ of the total phytomacrofauna population, Mollusca had 454 individuals accounting for $23.45 \%$ while, Annelida was represented by 22 individuals of polychaetes and constituted $1.11 \%$. Total individuals observed at the sampling stations varied between 82 and 368 . Number of species recorded in the sampling stations ranged from $13-24$. There was significant difference in the number of individuals recorded for the sampling stations (ANOVA, $\mathrm{F}=2.643$, $p<0.05$ ), a post-hoc test using Tukey's HSD shows that number of individuals observed in stations 2, 7 and 8 were significantly lower than those of other sampling stations. The spatial variations in the results recorded suggest that the phytomacrofauna community was influenced by site specific factors particularly with respect to depth of study stations as shown by correlation analyses carried out. (C) JASEM
\end{abstract}

\section{https://dx.doi.org/10.4314/jasem.v21i3.22}

Keywords: Water hyacinth, Phytomacrofauna, distribution, community structure, Iyagbe lagoon

Aquatic macrophytes play significant role in structuring communities in aquatic environments (Bass et. al., 1997). Macrophytes provide physical structure, increase habitat complexity and heterogeneity and affect the biology, bio-ecology and ecology of various organisms like invertebrates, fishes and water-birds in different ways. However, under invasive condition aquatic macrophyte may disrupt the ecological balance in the aquatic system. In general, major effects of macrophyte invasion include; changes in the composition of the indigenous macrophyte assemblage (Miller and Death, 1997) which results in restructuring of aquatic habitats, change in waterscape with concomitant impact on other taxonomic groups. Alteration in the assemblage due to changes in vegetation composition could lead to distruption in biotic relationships among species (Smock and Stoneburner, 1980) and, in extreme circumstances may cause species extinction (Carpenter and Lodge, 1986). Most invasive species have the tendency to out-compete native species and occupy their space thereby resulting in homogenization of the vegetative assemblage (Akinyemiju, 1987).

Homogenization in species composition has been shown to alter the physical structure of the habitat transform aquatic systems into dense stands of monocultures, causing devastating effects on the entire native biota (Miller and Death, 1997). Under homogenized conditions the diversity of organisms such as fishes and invertebrates can also be affected, due to decreases in shelter and foraging site variability. Homogenization can hypothetically affect food-web bases once it influences food resource quality. For example, periphyton richness increases with macrophyte diversity, which can be assumed to be a surrogate for the physical and/or biological structure provided for colonization (Beckett et al., 2011)

Effects on the periphytic community and direct effects of habitat complexity (mainly refugia and foraging sites) mediate a chain of mechanisms that 
may affect other trophic levels; for example, epiphytic grazers may increase due to alteration in habitat structure, which could support an increase in sites available for colonization by algae (Kurashov et al., 1996). In addition, alteration in habitat structure could affect relative abundances of organisms. Sloey et al. (1997) recorded changes in invertebrate assemblage composition due to structural changes and reduced water movement. All of these changes are partially mediated by habitat complexity variations, such that dominance by invasive macrophytes may also affect communities via these mechanisms.

Although negative effects are always expected from species invasions, neutral or positive results can be found (Tokeshi and Pinder, 1985), showing dichotomous effects for the invasion process. For example, habitat structure provided by invasive macrophyte beds can be increased in relation to native beds (through an increase in biomass, physical structuring and available area for organism colonization (Sloey et al., 1997; Brown et al., 1988), allowing greater epiphyton biomass, benthic invertebrate density and fish species occupation (Kelly and Hawes, 2005). Thus, positive effects of invasive species may be accentuated when they colonize sites lacking native macrophytes, increasing the habitat structure in these locations. In other situations, the great similarity among non-native and native species does not promote associated assemblage changes (Cyr and Downing, 1988a, b).

Structural complexity may be more important than other characteristics when invasion takes place (Cyr and Downing, 1988a), where the invading species can co-exist with non-native species, this could still offer new possibilities for habitat exploration and the species may contribute to biodiversity increases where they do not demonstrate invasiveness (Miller and Death, 1997). So, invasions may enhance habitat complexity in some ecosystems, however, negative effects on native communities are expected especially when a single species dominates the community and leads the ecosystem to become less physically and biologically heterogeneous.

Although a number of investigations have been carried out on phytomacrofauna community in several aquatic systems around the world (e.g. Dvorak and Best, 1982; Cyr and Downing, 1988a, b; Sloey et al., 1997; Miller and Death, 1997; Fieldman, 2001), in Africa (e.g. Edmunds, 1978; Yankson and Kendall, 2001) and in Nigeria (e.g. Egborge, 1988; Saliu, 1989; Uwadaiae, et al., 2011), no study has reported the phytomacrofaunal community of Iyagbe Lagoon. In this study, the composition, community structure and spatial distribution of phytomacrofauna community in a homogenized water hyacinth dominated macrophyte assemblage in Iyagbe Lagoon was investigated with a view to determining the factors responsible for observed patterns.

\section{MATERIALS AND METHODS}

Study Area: Iyagbe Lagoon is a two-arm lagoon (Fig. 1) comprised of the Porto-Novo Creek as one arm and Badagry Creek as another. The lagoon spans between Latitude $6^{\circ} 23^{\prime} \mathrm{N}$ and Longitude $3^{\circ} 06^{\prime} \mathrm{E}$ and separated from the ocean by its low lying barrier bar system along the Western Nigeria shoreline. The only opening to the ocean is through the Lagos Habour which links directly with the Lagos lagoon (Hill and Webb, 1958). The lagoon experiences dualseasonal pattern in the annual rainfall distribution which tends to regulate the salinity and water level. The surface of the lagoon is covered with varied mass of water hyacinth distributed in patches at different points especially close the lagoon shore. The lagoon is tidal and the entry of salt water from the sea through the Lagos Harbour gives rise to saline conditions in areas closer to the Lagos Lagoon. Tidal incursion of salt water and freshwater inflow into the lagoon has created a salinity gradient typical of aquatic systems in this region, and this has an overriding influence on the composition and distribution of biota (Hill and Webb, 1958; Uwadiae, 2009). Eight sampling points (Table 1) characterized by different degrees of fresh and salt water inundation with varied numbers of water hyacinth stand were chosen across the two arms of the lagoon for this study.

Sampling protocol : Sampling for environmental quality parameters and phytomacrofauna were carried out between 10:00 and 15:00 hrs on each sampling day at monthly intervals between November, 2013 May, 2014.

In situ measurements and collection of samples: In situ measurements of surface water $\mathrm{pH}$, Total dissolved solid (TDS) and Total suspended solid (TSS) were carried out using battery operated Horiba U10 Water Quality Checker Model. Transparency was determined using a $20 \mathrm{~cm}$ diameter Secchi disk painted black and white. Depth of sampling stations was determined using wooden pole which was place in the water and water level mark and read against a measuring tape and value recorded in metres. Water samples for the determination of dissolved oxygen (DO) and biochemical oxygen demand (BOD) were collected in transparent and amber coloured $250 \mathrm{ml}$ reagent bottles. The samples for DO were fixed on 
the field with $1 \mathrm{ml}$ each of Winkler's solutions A (Manganese sulphate) and B (Sodium hydroxide and sodium hydroxide). Water samples for the analysis of Biochemical Oxygen Demand (BOD) were collected with $250 \mathrm{ml}$ prewashed amber coloured reagent bottles. The water sample in the transparent bottle was fixed with $1 \mathrm{ml}$ each of Winkler's solutions A and $\mathrm{B}$, while the water samples in the amber coloured bottle were taken to the laboratory and incubated for 5 days at $20{ }^{\circ} \mathrm{C}$ (APHA, 1985). Samples for the analysis of other physico-chemical properties of water were taken below the water hyacinth canopy in each sampling sites before organisms were sampled in order to avoid sampling disturbance of water quality.

Phytomacrofauna samples were collected within water hyacinth canopy by placing a $0.1 \mathrm{~m}^{2}$ quadrant over stands of the plant, the roots of water hyacinth stands enclosed in the quadrant were carefully removed and placed in a bowl containing $10 \%$ formalin solution (this facilitates removal of attached organism). The plants were then vigorously shaken to detach all the animals inhabiting the roots into the bowl. Detached animals were then washed into a screw cap plastic container through a $0.5 \mathrm{~mm}$ mesh size sieve. The remaining animals were hand-picked into the plastic container. The samples were fixed in $10 \%$ formalin solution and taken to the laboratory for analyses.

Sample analyses: Dissolved oxygen and BOD of water samples were determined according to the methods described in APHA (1985). In the laboratory, macroinvertebrate samples were washed to remove the fixative and sorted under a dissecting microscope. Specimens of phytomacrofauna were identified to the lowest possible taxonomic level using the available keys of Edmunds (1978), Yankson and Kendal (2001) and Bouchard (2004). Numbers of individuals in each sampling station and the month collected were recorded.

Table 1: Global Positioning System location and some physical attribute of the study sites.

\begin{tabular}{|c|c|c|c|c|c|}
\hline 苞 & 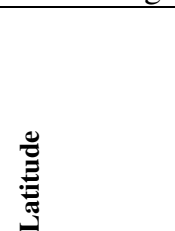 & 苛 & 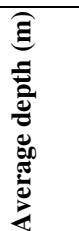 & 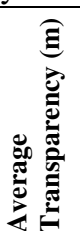 & 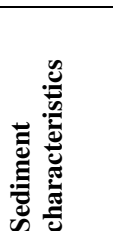 \\
\hline 1 & $6^{\circ} 241.651 \mathrm{~N}$ & $3^{\circ} 191.812 \mathrm{E}$ & 0.93 & 0.47 & Sandy \\
\hline 2 & $6^{\circ} 241.676 \mathrm{~N}$ & $3^{\circ} 161.938 \mathrm{E}$ & 0.93 & 0.39 & Sandy \\
\hline 3 & $6^{\circ} 251.582 \mathrm{~N}$ & $3^{\circ} 142.529 \mathrm{E}$ & 0.77 & 0.39 & Sandy \\
\hline 4 & $6^{\circ} 241.632 \mathrm{~N}$ & $3^{\circ} 131.705 \mathrm{E}$ & 0.87 & 0.58 & Muddy \\
\hline 5 & $6^{\circ} 251.603 \mathrm{~N}$ & $3^{\circ} 111.990 \mathrm{E}$ & 0.74 & 0.44 & Muddy \\
\hline 6 & $6^{\circ} 261.551 \mathrm{~N}$ & $3^{\circ} 111.239 \mathrm{E}$ & 1.59 & 0.58 & Muddy \\
\hline 7 & $6^{\circ} 261.134 \mathrm{~N}$ & $3^{\circ} 131.224 \mathrm{E}$ & 1.44 & 0.51 & Muddy \\
\hline 8 & $6^{\circ} 251.755 \mathrm{~N}$ & $3^{\circ} 191.915 \mathrm{E}$ & 1.69 & 0.67 & Sandy \\
\hline
\end{tabular}

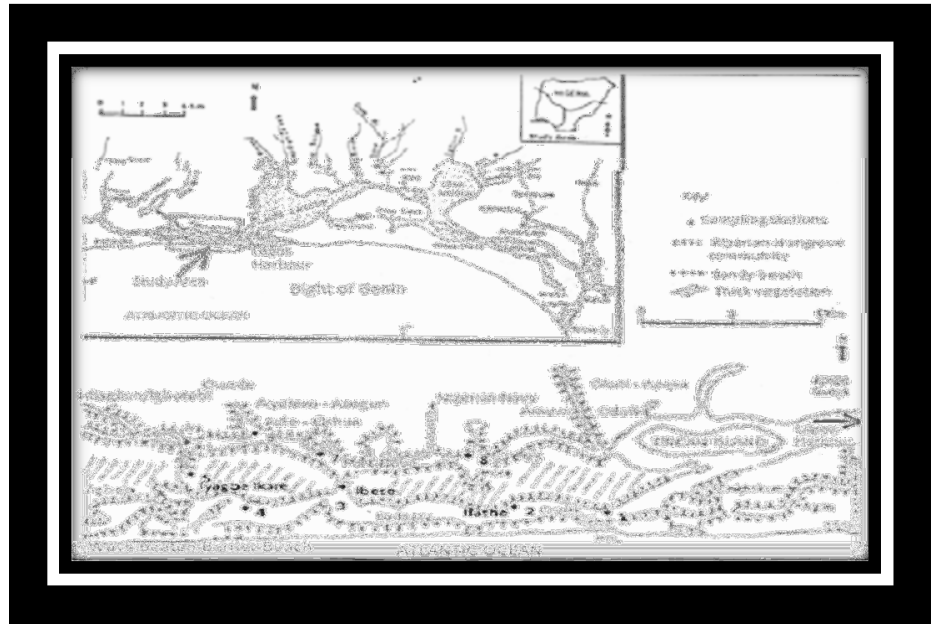

Fig. 1: Map of study area showing sampling stations 
Full-text Available Online at www.ajol.info and www.bioline.org.br/ja
Statistical analysis: One-Way analysis of variance (ANOVA) was used to compare the variations in phytomacrofauna variables at the study sites. When significant variations are detected, a post hoc test using Tukey's Honestly Significantly Different (HSD) test was performed to determine the locations of significant differences. The relationships between biotic and environmental parameters were determined using Spearman rank correlations (Sokal and Rohlf, 1981). All statistical analyses were performed with SPSS 10 and Excel 2013 for Windows.

\section{RESULTS AND DISCUSSION}

Environmental conditions in water hyacinth canopy

Table 2 shows the summary of the physico-chemical conditions in the study area. Overall trends in water quality were relatively consistent for study sites. A range of $3.0-3.9 \mathrm{mg} / \mathrm{L}, 1.1-1.7 \mathrm{mg} / \mathrm{L}$ and $40-119$ $\mathrm{cm}$ were recorded for DO, BOD and transparency respectively. Values obtained for other parameters ranged from $0.52-50.0 \mathrm{mg} / \mathrm{L}, 0.02-20.10 \mathrm{mg} / \mathrm{L}$ and $5.34-8.90$, for Total dissolved solids (TDS), Total suspended solid (TSS) and $\mathrm{pH}$.

Table 2: Summary of physical and chemical conditions at the sampling stations

\begin{tabular}{|c|c|c|c|c|c|c|c|c|c|c|c|c|}
\hline \multirow{3}{*}{ Parameters } & \multicolumn{12}{|c|}{ Sampling stations } \\
\hline & \multicolumn{3}{|c|}{1} & \multicolumn{3}{|c|}{2} & \multicolumn{3}{|c|}{3} & \multicolumn{3}{|c|}{4} \\
\hline & Mean \pm SD & Min & Max & Mean \pm SD & Min & Max & Mean \pm SD & Min & Max & Mean \pm SD & Min & Max \\
\hline $\begin{array}{l}\text { Dissolved } \\
\text { Oxygen (mg/L) }\end{array}$ & $3.67 \pm 0.20$ & 3.5 & 3.9 & $3.55 \pm 0.29$ & 3 & 3.8 & $3.62 \pm 0.08$ & 3.5 & 3.7 & $3.53 \pm 0.21$ & 3.2 & 3.7 \\
\hline $\begin{array}{l}\text { Biochemical } \\
\text { Oxygen } \\
\text { Demand }(\mathrm{mg} / \mathrm{L})\end{array}$ & $1.28 \pm 0.16$ & 1.1 & 1.5 & $1.28 \pm 0.08$ & 1.2 & 1.4 & $1.22 \pm 0.08$ & 1.1 & 1.3 & $1.32 \pm 0.13$ & 1.2 & 1.5 \\
\hline $\begin{array}{l}\text { Total Dissolved } \\
\text { Solids (mg/L) }\end{array}$ & $3.34 \pm 2.29$ & 0.14 & 7.18 & $25.81 \pm 20.32$ & 0.65 & 50 & $13.81 \pm 18.60$ & 0.65 & 50 & $9.86 \pm 8.08$ & 2.7 & 25 \\
\hline $\begin{array}{l}\text { Total Suspended } \\
\text { Solids (mg/L) }\end{array}$ & $0.89 \pm 0.96$ & 0.02 & 2.14 & $4.55 \pm 2.73$ & 0.11 & 6.78 & $4.96 \pm 7.60$ & 0.05 & 20.1 & $3.25 \pm 3.55$ & 0.2 & 10.22 \\
\hline \multirow{3}{*}{$\begin{array}{l}\text { Surface Water } \\
\mathrm{pH}\end{array}$} & $7.63 \pm 1.00$ & 6.19 & 8.9 & $7.61 \pm 0.76$ & 6.52 & 8.2 & $7.36 \pm 1.10$ & 5.74 & 8.8 & $7.58 \pm 0.98$ & 6.11 & 8.9 \\
\hline & & 5 & & & 6 & & & & & 8 & & \\
\hline & Mean+SD & Min & Max & Mean+SD & Min & Max & Mean+SD & Min & Max & Mean+SD & Min & Max \\
\hline $\begin{array}{l}\text { Dissoved } \\
\text { Oxygen (mg/L) }\end{array}$ & $3.60 \pm 0.32$ & 3 & 3.9 & $3.58 \pm 0.08$ & 3.5 & 3.7 & $3.50 \pm 0.27$ & 3 & 3.7 & $3.57 \pm 0.10$ & 3.4 & 3.7 \\
\hline $\begin{array}{l}\text { Biochemical } \\
\text { Oxygen } \\
\text { Demand }(\mathrm{mg} / \mathrm{L})\end{array}$ & $1.22 \pm 0.13$ & 1.1 & 1.4 & $1.30 \pm 0.23$ & 1.1 & 1.7 & $1.32 \pm 0.18$ & 1.1 & 1.5 & $1.34 \pm 0.17$ & 1.2 & 1.6 \\
\hline $\begin{array}{l}\text { Total Dissolved } \\
\text { Solids (mg/L) }\end{array}$ & $\begin{array}{l}20.47 \\
\pm 17.12\end{array}$ & 2 & 50 & $6.93 \pm 5.99$ & 0.65 & 16.7 & $8.12 \pm 9.33$ & 0.52 & 25 & $17.46 \pm 17.79$ & 2.25 & 50 \\
\hline $\begin{array}{l}\text { Total Suspended } \\
\text { Solids (mg/L) }\end{array}$ & $4.09 \pm 3.17$ & 0.08 & 8 & $1.97 \pm 1.65$ & 0.05 & 4.8 & $2.08 \pm 2.11$ & 0.12 & 5.65 & $6.13 \pm 6.49$ & 1.05 & 18.45 \\
\hline $\begin{array}{l}\text { Surface Water } \\
\mathrm{pH}\end{array}$ & $6.88 \pm 1.17$ & 5.55 & 8.3 & $7.03 \pm 0.99$ & 5.34 & 8.1 & $7.27 \pm 1.30$ & 5.56 & 8.8 & $7.20 \pm 0.77$ & 6.31 & 8.4 \\
\hline
\end{tabular}

Community composition and spatial distribution of phytomacrofauna: Table 3 and Figs 2 - 6 illustrate the variations in phytomacrofauna variables at the sampling stations while the percentage representation of major phytomacrofauna taxa in Iyagbe Lagoon is shown in Fig. 7. Three major phytomacrofauna groups (Annelida, Arthropoda and Mollusca) were identified from a total of 1,976 individuals of phytomacrofauna recorded in the study area. Arthropoda was the most abundant group with a total of 1,500 individuals and accounted for about $76 \%$ of the total macroinvertebrate population. Three major classes of arthropods (Arachnida, Crustacean and Insecta) comprising 13 families and 14 species were identified from the study area. Crustacean was the most abundant group with total 1421 individuals and accounted for $94.7 \%$ of the total arthropod population. This group was represented by 5 species from 5 families. Among the Crustacean recorded, the crab Panaeus notialis was the most abundant with 681 individuals and accounted for about $48 \%$ of crustacean population. Also significantly represented in the crustacean group is another crab Sesarma huzardii, which accounted for $22 \%$ (284 individuals) of Crustacean population. In the overall, these two organisms dominated the phytomacrofauna community in the study stretch.

A total of 76 individuals comprising 8 species from 8 families were recorded for the group Insecta. This group accounted for $5.0 \%$ of the total arthropods recorded. Among the insects observed, Chironomus 
plumosus was most abundant with 23 individuals and constituted $31.3 \%$ of the insect population. Also significantly represented among the insects are Culicoides impunctactus and Paragomphus lineatus. These two species recorded 100 and 130 individuals and accounted for $13.2 \%$ and $17.1 \%$ respectively. Agyroneta aquatica was the only species of Arachnida observed in this study, it constituted $0.2 \%$ of the total arthropod population.
Mollusca represented by 2 classes, 5 families and 10 species had 454 individuals accounting for $23.45 \%$ of total phytomacrofauna population. Pachymelania aurita with 82 individuals, Neritina glabarata and Macoma cumana with 57 individuals each, and Tellina nymphalis with 51individuals were the major representatives in the Mollusc group. Annelida was represented by 4 species of polychaetes. With the 22 individuals collected, Annelids constituted $1.11 \%$ of the total phytomacrofauna population.

Table 3: Variations in the number of taxa and individuals contributed by phytomacrofauna families at the sampling stations

\begin{tabular}{|c|c|c|c|c|c|c|c|c|c|c|c|c|c|c|c|c|}
\hline \multirow{4}{*}{ Taxa } & \multicolumn{14}{|c|}{ Sampling Stations } & \multirow{2}{*}{\multicolumn{2}{|c|}{8}} \\
\hline & 1 & & 2 & & 3 & & 4 & & 5 & & 6 & & 7 & & & \\
\hline & & & & & & & & & & & & & & & & \\
\hline & $\begin{array}{l}\text { U' } \\
\dot{0} \\
z\end{array}$ & $\begin{array}{l}\text { Uे } \\
0 \\
\dot{z}\end{array}$ & $\begin{array}{l}\text { U' } \\
\text { Zे }\end{array}$ & $\begin{array}{l}\tilde{0} \\
\dot{0} \\
z\end{array}$ & $\begin{array}{l}\text { U' } \\
\text { ㅇ }\end{array}$ & $\begin{array}{l}\tilde{0} \\
0 \\
0\end{array}$ & $\begin{array}{l}\text { U' } \\
\stackrel{0}{z}\end{array}$ & $\begin{array}{l}\text { U' } \\
\dot{0} \\
z\end{array}$ & $\begin{array}{l}\text { Ũ } \\
\text { Z }\end{array}$ & $\begin{array}{l}\text { 'ँ } \\
\circ \\
\text { z }\end{array}$ & $\begin{array}{l}\text { Ũ } \\
\text { ż }\end{array}$ & $\begin{array}{l}\text { Ü } \\
\circ \\
\text { z }\end{array}$ & $\begin{array}{l}\text { t' } \\
\dot{0} \\
z\end{array}$ & $\begin{array}{l}\text { Uे } \\
0 \\
\dot{z}\end{array}$ & $\begin{array}{l}\text { Ũ } \\
\text { ż }\end{array}$ & $\begin{array}{l}\text { Uे } \\
\text { ○ } \\
\text { Z }\end{array}$ \\
\hline Capitellidae & & & 1 & 1 & & & 1 & 1 & & & & & & & 1 & 1 \\
\hline Chironomidae & 1 & 1 & 1 & 2 & 1 & 1 & 1 & 6 & 1 & 5 & 1 & 3 & 1 & 3 & 1 & 2 \\
\hline Ceratopogonidae & & & & & & & 1 & 3 & 1 & 4 & 1 & 2 & 1 & 1 & & \\
\hline Gomphidae & 1 & 1 & & & & & 1 & 5 & 1 & 3 & 1 & 2 & 1 & 1 & 1 & 1 \\
\hline Cordulegastridae & & & & & & & 1 & 2 & 1 & 2 & 1 & 1 & & & & \\
\hline Philopotamidae & & & & & & & 1 & 2 & & & & & 1 & 1 & & \\
\hline Amphilochidae & 1 & 20 & 1 & 11 & 1 & 23 & 1 & 23 & 1 & 10 & 1 & 17 & 1 & 16 & 1 & 8 \\
\hline Penaeidae & 1 & 130 & 1 & 75 & 1 & 123 & 1 & 86 & 1 & 112 & 1 & 91 & 1 & 46 & 1 & 18 \\
\hline Cirolanidae & 1 & 21 & 1 & 4 & 1 & 16 & 1 & 24 & 1 & 5 & 1 & 130 & 1 & 12 & 1 & 11 \\
\hline Idoteidae & 1 & 20 & 1 & 12 & 1 & 26 & 1 & 12 & 1 & 23 & 1 & 4 & 1 & 8 & & \\
\hline Sesarmidae & 1 & 65 & 1 & 23 & 1 & 14 & 1 & 44 & 1 & 42 & 1 & 46 & 1 & 31 & 1 & 19 \\
\hline Neritidae & 2 & 19 & 2 & 10 & 2 & 5 & 2 & 10 & 2 & 34 & 2 & 4 & 2 & 9 & 2 & 5 \\
\hline Planorbidae & & & & & & & 1 & 3 & 1 & 14 & 1 & 5 & 1 & 3 & & \\
\hline Melanidae & 2 & 30 & 2 & 13 & 2 & 7 & 2 & 16 & 2 & 33 & 2 & 12 & 2 & 15 & 2 & 6 \\
\hline Potamididae & 1 & 13 & 1 & 2 & 1 & 3 & 2 & 9 & 1 & 13 & 1 & 4 & 2 & 10 & 1 & 3 \\
\hline Tellinidae & 2 & 17 & 2 & 9 & 2 & 9 & 2 & 12 & 2 & 31 & 2 & 10 & 2 & 11 & 2 & 9 \\
\hline
\end{tabular}

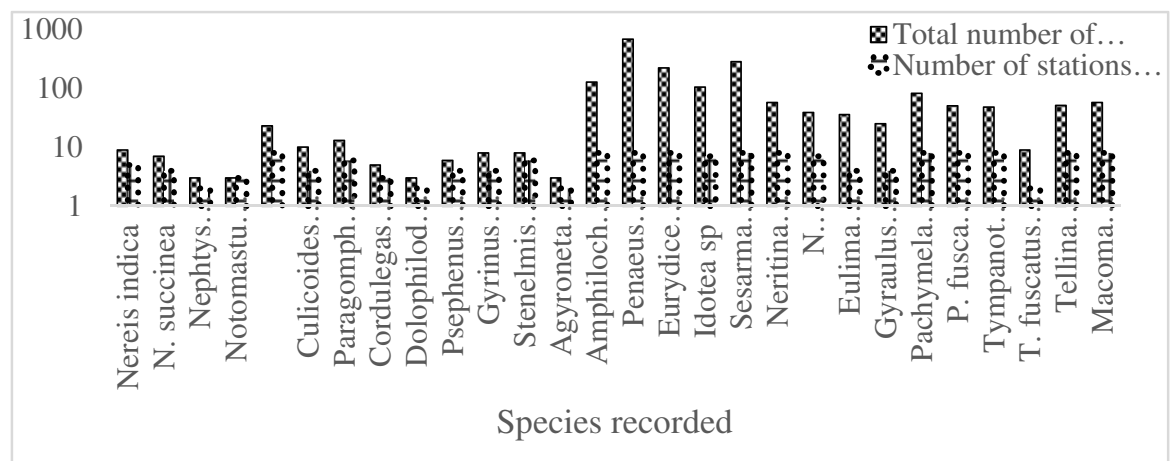

Fig 2: Phytomacrofauna species abundance and number of sampling stations they occurred 


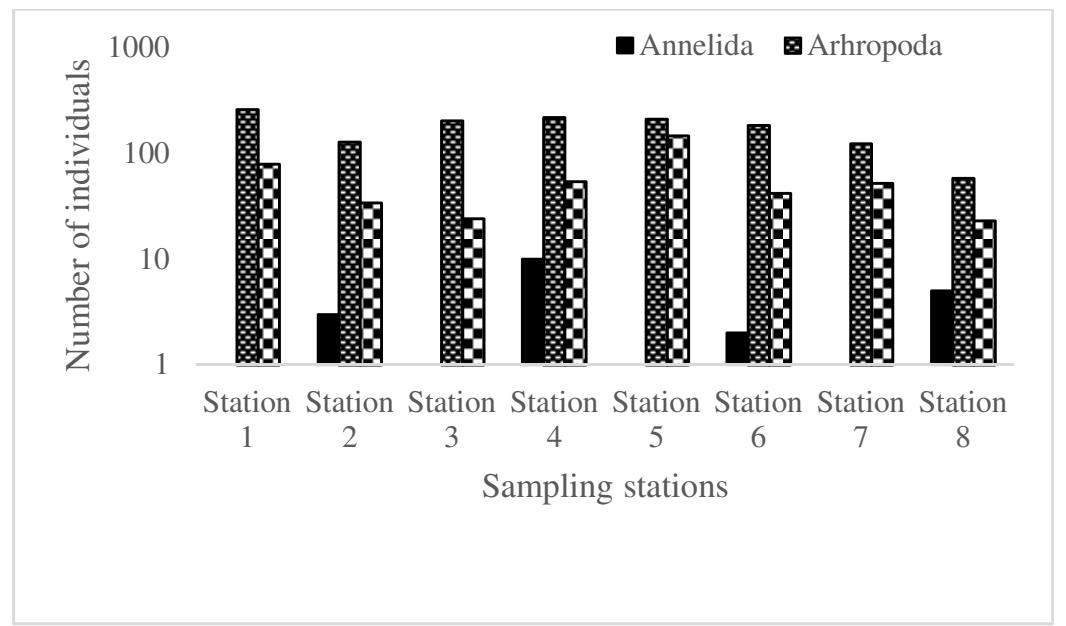

Fig. 3: Variations in the total number of individuals contributed by the different phyla at the sampling stations.

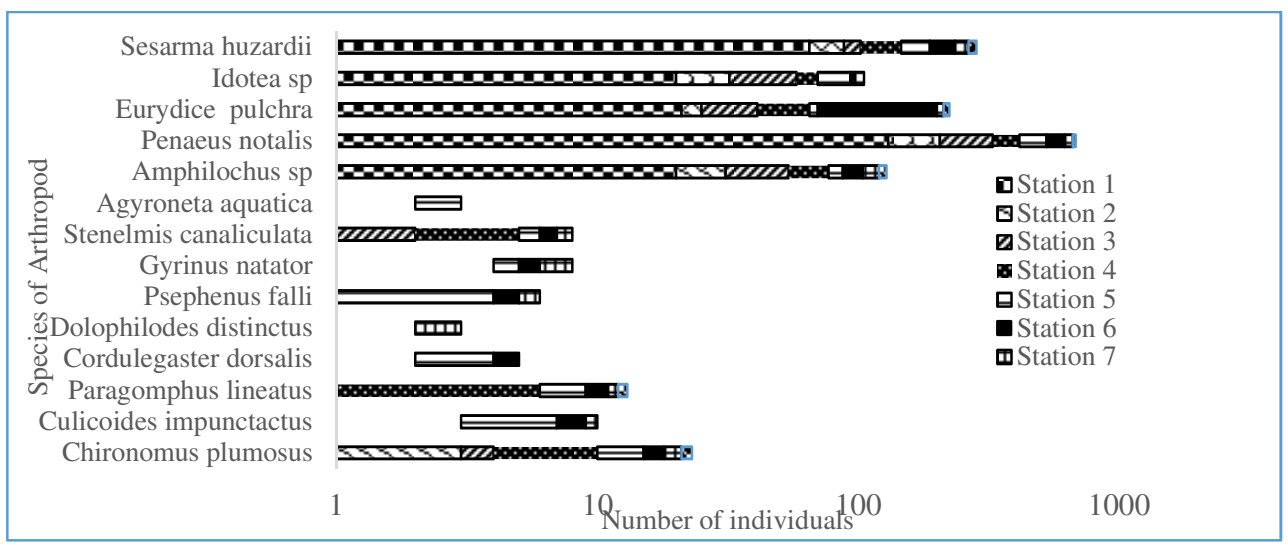

Fig. 4: Variation in the number of individuals of Arthropod species in the sampling stations

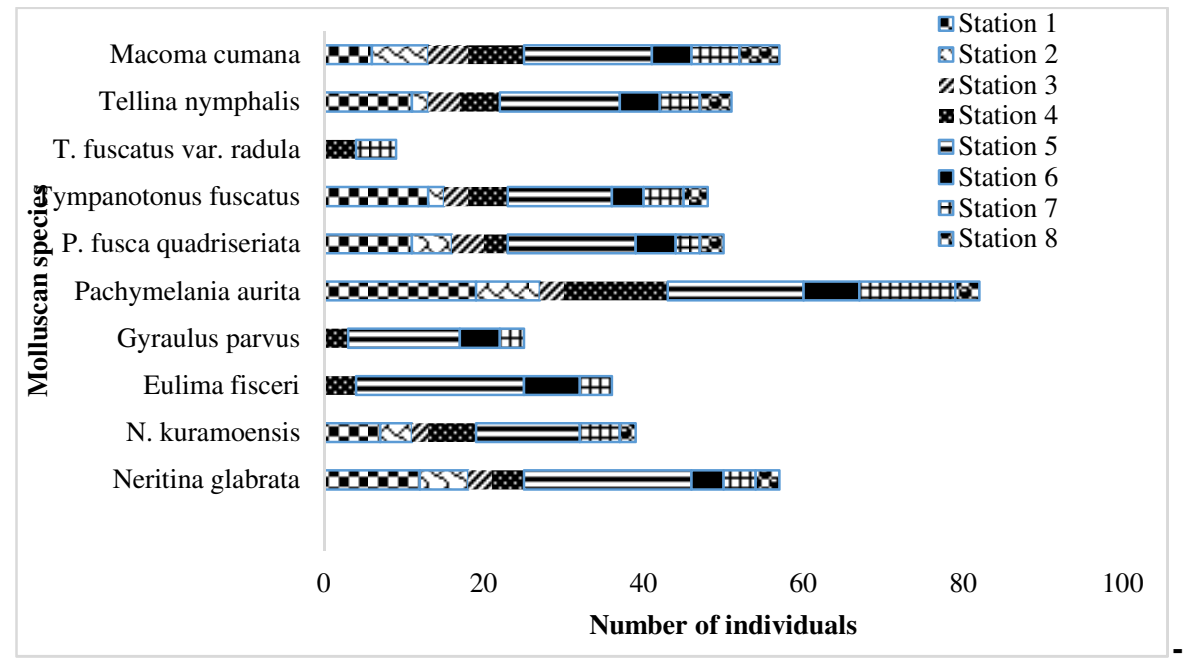

Fig. 5: Variation in the number of individuals of Mollusc species in the sampling stations 


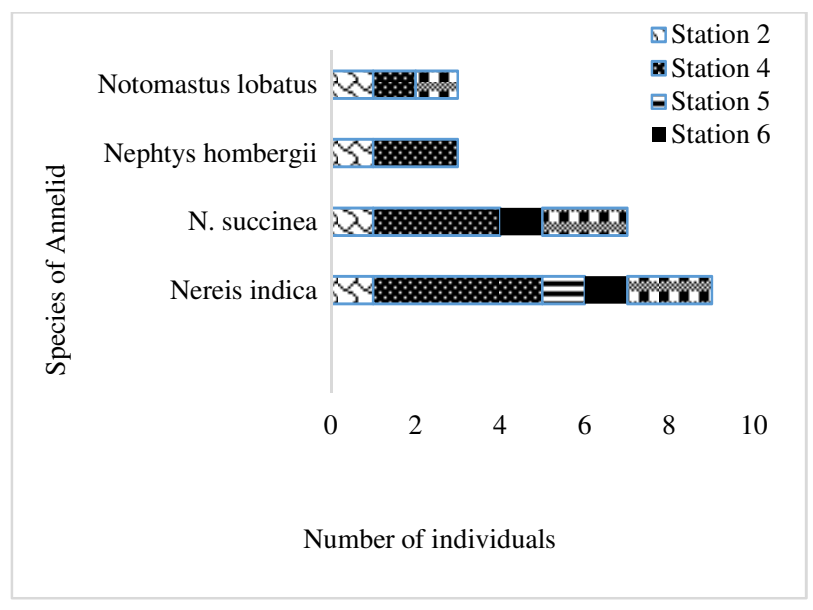

Fig. 6: Variation in the numbers of individuals of Annelid species at the sampling stations

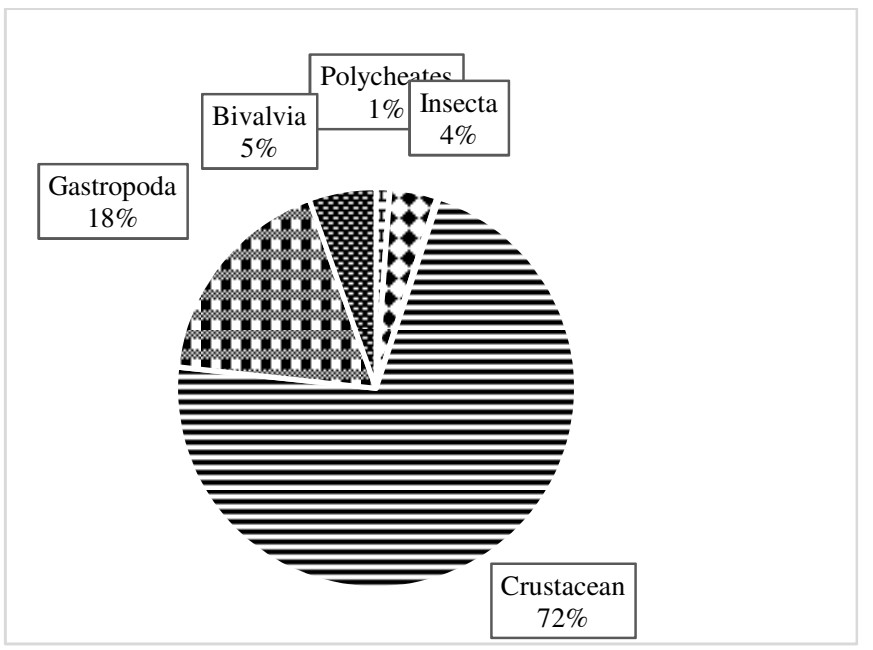

Fig. 7: Overall percentage representation of major phytomacrofauna taxa in Iyagbe Lagoon.

High variability in the numbers of individuals and species of phytomacrofuna was observed in the sampling stations (Fig. 8). There was no particular trend shown in the number of individuals enumerated at the sampling stations. Total number of individuals recorded at the sampling stations varied between 82 individuals observed in station 8 and 368 individuals collected in station 5. Stations 6 and 1 ranked second and third in the number of individuals in sampling stations with 341 and 337 individuals respectively collected from the two stations. Total number of individuals recorded for other stations were; 271 for station 4, 228 for station 3, 175 for station 7, and 162 for station 2. There was significant difference in the number of individuals recorded for the sampling stations (ANOVA, $\mathrm{F}=2.643, p<0.05$ ), a post-hoc test using Tukey's HSD shows that number of individuals observed in stations 2, 7 and 8 were significantly lower than those of other sampling stations.
Variation in the distribution of individual species was mainly influenced by class and individual related attributes. Crustaceans were recorded in all the sampling stations although there was high variability in the numbers of individuals of species represented across the sampling stations. All crustacean species collected were present in all the sampling stations except Idotea sp which was absent in samples collected from station 8. Among the molluscs, Neritina glabrata, Pachymelania aurita, P. fusca quadriseriata, Tympanotonus fuscatus, Tellina nymphalis, and Macoma cumana were recorded in all the sampling stations. Neritina kuramoensis was absent in samples collected from station 6 while, $T$. fuscatus var. radula was only recorded in stations 4 and 7. The freshwater gastropods (Eulima fisceri, Gyraulus parvus) were restricted to stations 4, 5, 6 and 7. All the species of arthropod were restricted to stations 4, 5, 6, and 7 in distribution except 
Chironomus plumosus, Paragomphus lineatus and Stenelmis canaliculata. Chironomus plumosus occurred in all the sampling stations. Paragomphus lineatus was also collected from stations 1 and 8 while Stenelmis canaliculata also occurred in stations 2 and 3.

Number of species recorded in the sampling stations ranged from 13 in station 8 and 24 in station 4 . Twenty-two species were recorded in each of stations 5 and 7 , while 14 each were observed in stations 1,2 and 3. Of all the species recorded in this study, the crustacean, Penaeus notalis was the most important in terms of population across the sampling stations. The species accounted for about $39 \%$ in station 1 , $46 \%$ in station 2, about 54 in station 3, 32\% in station $4,31 \%$ in station $5,27 \%$ in station $6,26 \%$ in station 7 and $21 \%$ in station 8. Eurydice pulchra was more important in station 6 where it constituted $38 \%$ of the total phytomacrofauna population. It was also the most important species in station 8 accounting for $23 \%$ of the total phytomacrofauna population.

There is no existing report on phytomacrofauna community of Iyagbe Lagoon, the discussion presented here therefore focuses mainly on the peculiar characteristics of the assemblage recorded and the most probable factors responsible for observed patterns. In terms of composition, the result obtained in this study relates favourably with those of other studies carried out in similar environments. The dominance of arthropods in phytomacrofuna community has been widely reported (Saliu, 1989;
Dvorak, 1996; Edokpayi et al.; 2008; Edokpayi, et al.; 2009; Edokpayi et al.; 2010; Beckett et al.; 2011; Uwadiae et al.; 2011) and this phenomenon has been attributed to number of factors. Firstly, most aquatic arthropods are known to use aquatic vegetation as their habitat. Beckett et al. (2011) observed that, the most important reason for making aquatic vegetation a habitat is the provision of shelter. According to their reports, different plants shelter different animals. The shapes of the plants themselves have been solely implicated in these differences. (Dvorak, 1996) observed that arthropods are more abundant on macrophytes which proves surface for colonization and protection.

Secondly, arthropods are attracted to macrophytes because of the availability of food in macrophyte beds. Shredders feed on vascular plant tissue, collectors feed on detrital particles, scrapers feed on attached algae and predators feed on live prey (Cummins, 1973; Newman, 1991). Apart from feeding on the tissues of the aquatic plant itself, the periphyton on the aquatic plants are also important food component for herbivorous arthropods (Dvorak, 1996). It has been noted that microhabitat selection in some aquatic arthropods may be related to availability of food and other nutritive substances (Cummins, 1973; Dvorak, 1996). Thirdly, many aquatic arthropods use aquatic vegetation for reproductive purposes. Aquatic arthropods are known to use macrophytes as suitable substrate for eggs deposition.

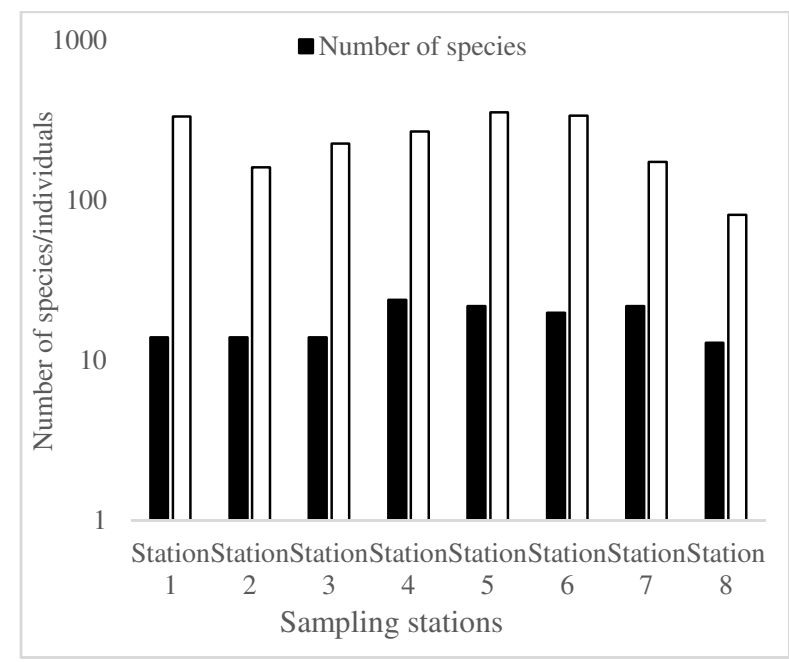

Fig. 8: Variations in the numbers of individuals and species at the sampling stations

Relationship between environmental parameters and biotic variables: Spearman's correlations between biotic and environmental parameters in the study area indicated that there was significant correlation between depth $\left(\mathrm{r}_{\mathrm{s}}=0.511 ; \mathrm{p}<0.5\right)$, transparency $\left(\mathrm{r}_{\mathrm{s}}=\right.$ $0.642, \quad \mathrm{p}<0.5)$ and number of individuals. 
Transparency also correlated significantly $\left(\mathrm{r}_{\mathrm{s}}=0.542\right.$, $\mathrm{p}<0.5)$ with number of phytomacrofauna species. In the overall relationship, transparency had strong influence on the pattern of phytomacrofauna assemblage recorded.

The community structure observed in this study is majorly a response to site specific environmental forces such as variation in structural complexity of water hyacinth bed, bed density, depth and transparency of water. As mentioned in the description of the study area, the distribution of water hyacinth in the part of the lagoon where this study was carried out was not uniform, but patchy. Most of the sampling stations were characterized by absence or presence of few stands of water hyacinth resulting in reduction of structural complexity. The relationship between habitat complexity and community structure has long been examined (Dvorak and Best, 1982) and two main hypotheses have been debated. First, the habitat diversity hypothesis (Williams, 1943) holds that, species diversity increases with increasing availability of different habitat types. Complex habitats provide a wider range of niches than simple ones and thus support more diverse assemblages (Dvorak and Best, 1982). Secondly, because complex habitats generally support more individuals than simple ones, the passive sampling hypothesis (Carpenter and Lodge, 1986) holds that more individuals give more species, since more individuals represent the available species pool more completely. Some authors examined this alternative to the habitat diversity hypothesis and showed that the number of individuals was the best single predictor of species richness (Angermeier and Schlosser, 1989).

The relatively low number of individuals in stations 2, 7 and 8 and the low number of species observed in station 8 may be due to low water hyacinth bed density and the resultant structural simplification of the bed. According to Dvorak and Best (1982), low plant density reduces the surface area for colonization by periphyton which serves as food for the invertebrates. Low plant density generally leads to low primary production and reduce shelter from fish predation, which appears generally to be important in structuring macroinvertebrate communities in plant beds (Bertolo, et al., 2005). Low plant density may expose attached organisms to erosive force or full strength of water flow, giving rise to selective colonization by only those species strong enough to adapt. The low density of water hyacinth bed and reduced structural complexity may also be responsible for the low number (28) of species recorded in this study compared to results from closely related environments. Uwadiae et al. (2011) reported 53 species of phytomacrofauna in Lekki Lagoon, owning ostensibly to the high density and structurally complex bed observed in the area. Although the number of individuals $(1,976)$ recorded in this study is higher than that $(1,240)$ of Lekki Lagoon, the water hyacinth bed in Lekki Lagoon provided a more complex bed that accommodated larger number of species than Iyagbe Lagoon. Reduced habitat complexity results in fewer colonization spaces for different species, hence species colonizing such areas proliferate in number due to the absence of or reduction in inter-specific competition.

The relatively higher water levels in stations 2, 7 and 8 may be responsible for the observed low number of individuals. Stations 4 and 5 which recorded relatively lower water levels and transparency had relatively higher number of individuals and species. This observation corroborates the findings of Ogbeibu (2001) which reported low faunal density during low water level in a temporary pond in southern Nigeria. Pearson's correlation coefficients calculated to assess relationship between density and physico-chemical parameters confirmed an inverse relationship between density and water level. The compact nature of the water hyacinth mat is known to restrict light penetration especially at great depths. Since periphyton growth and development are poor at depths with low light penetration, phytomacrofauna assemblage may be poor because, periphyton serves as food for phytomacrofauna. Periphyton density declines with depth due to shading effects from phytoplankton (LaLonde and Downing, 1991; Dudley, 1998) and plant biomass in the upper water column (Cattaneo et al., 1998). Cattaneo et al. (1998) observed that increased light penetration resulted in higher periphyton densities at greater depths in coontail beds. Such a relationship might be particularly evident for this assemblage, given the importance of periphyton food resources to the diet of most phytomacrofauna recorded.

Conclusion: Although it is widely believed that invasive species like the water hyacinth impact negatively on the ecosystem, this study has shown that, impacts are largely dependent on site-specific factors; hence, studies investigating the possible ecological consequences of invasive species should look out for site/area-related parameters responsible for observed patterns. 


\section{REFERENCES}

Akinyemiju, OA. (1987). Invasion of Nigeria waters by water hyacinth. Journal of Aquatic Plant Management 25: 24 - 26.

Angermeier, PL.; Schlosser, IJ. (1989). Species-area relationships for stream fishes. Ecology 70(5):1450-1462

American Public Health Association (APHA) (1985). Standard Methods for the Examination of Water and Wastewater. 16th edn. American Public Health Association, Washington, DC.

Bass, J.A., Leach, D.V. and Pinder, L.C. (1997). The invertebrate community of submerged Nuphar lutea (L.) leaves in the great Ouse. Regul. Riv. 13: 259-266.

Beckett, DC; Aartila, TP; Miller, AC. (2011). Invertebrate abundance on Potamogeton nodosus: effects of plant surface area and Community structure of phytomacrofauna in a tropical lagoon Pan-American Journal of Aquatic Sciences 6(1): 44-56

Bertolo, A; Carignan, R; Magnan, P; Pinel-Alloul, B; Planas, D; Garcia, E. (2005). Decoupling of pelagic and littoral food webs in oligotrophic Canadian Shield lakes. Oikos 111: 534-546.

Bouchard RW.Jr. (2004). Guide to aquatic macroinvertebrates of the Upper Midwest. Water Resources Center, University of Minnesota, St. Paul, MN.

Brown, CL; Poe, TP; French III, JRP; Schlosser, DW. (1988). Relationships of phytomacrofauna to surface area in naturally occurring macrophyte stands. Journal of North American Benthological Society 7: 129-139.

Carpenter, SR; Lodge, DM. (1986). Effects of submersed macrophytes on ecosystem processes. Aquatic Botany 26: 341-370.

Cattaneo, A.; Galanti, G.; Gentinetta, S.; Romo, S. (1998). Epiphytic algae and macroinvertebrates on submerged and floating-leaved macrophytes in an Italian lake. Freshwater Biology, 39: 725740 .

Cummins, KW. (1973). Trophic relations of aquatic insect. Ann. Rev. Ent. 18: 183 - 206.
Cyr, H; Downing, JA. (1988a). Empirical relationships of phytomacrofaunal abundance to plant biomass and macrophyte bed characteristics. Canadian Journal of Fisheries and Aquatic Sciences 45: 976-984.

Cyr, H; Downing, JA. (1988b). The abundance of phytophilous invertebrates on different species of submerged macrophytes. Freshwat. Biol. 20: 365 -374 .

Dudley, TL. (1988). The roles of plant complexity and epiphyton in colonization of macrophytes by stream insects. Limnology 23:1153-1158.

Dvorak, J. (1996). An example of relationships between macrophytes, macroinvertebrates and their food resources in a shallow eutrophic lake. Hydrobiologia 339: 27-36

Dvorak, J; Best. EPH. (1982). Macro-invertebrate communities associated with the macrophytes of Lake Vechten: structural and functional relationships. Hydrobiologia 95: 115 - 126.

Edmunds J. (1978). Sea shells and molluscs found on West African Coasts and Estuaries. Ghana University Press, Accra.

Edokpayi, CA; Uwadiae, RE; Asoro, AO; Badru, AE. (2008). Phytomacroinvertebrates arthropods associated with the roots of Eichorrnia crassipes (water hyacinth) in a tropical West African Lagoon. Ecology, Environment and Conservation 14: 241-247.

Edokpayi, CA; Uwadiae, RE; Oluwarotimi, OT. (2009). The physicochemistry and phytomacrofauna communities associated with Pistia stratiotes (L.) (Water lettuce) in a nontidal creek within the University of Lagos, southwest, Nigeria. The Journal of Science and Developmen 11: 62-76.

Edokpayi, CA; Uwadiae, RE; Njar, CE. (2010). Noninsect benthic phytomacrofauna and organismwater quality relations in a tropical coastal Ecosystem: impact of land based pollutants. Journal of American Science 6: 213-220.

Egborge, ABN. (1988). Water hyacinth-Biological Museum. Proceedings of the International Workshop on water hyacinth, Lagos. $7-12$ August. $52-70$. 
Feldman, RS. (2001). Taxonomic and size structures of phytophilous macroinvertebrate communities in Vallisneria and Trapa beds of the Hudson River, New York. Hydrobiologia 452: 233 245.

Hill MB; Webb JE. (1958). The Ecology of Lagos Lagoon II: The Topography and physical features of Lagos Harbour and Lagos Lagoon. Philosophical Transaction of the Royal Society of London. Series B. Biological Sciences, 241:319-333.

Kelly, D; Hawes L (2005). Effects of invasive macrophytes on littoral-zone productivity and foodweb dynamics in a New Zealand highcountry lake._ Journal of the North American Benthological Society 24(2):300-320 •

Kurashov, EA; Telesh, IV; Panov, EV; Usenko, NV; Rychkova, MA. (1996). Invertebrate communities associated with macrophytes in Lake Ladoga: Effects of environmental factors. Hydrobiologia 322:49-55.

Lalonde, S.; J. A. Downing. (1991). Epiphyton biomass is related to lake trophic status, depth, and macrophyte architecture. Can. J. Fish. Aquat. Sci. 48: 2285-2291.

Miller, RJ; Death, RG. (1997). Seasonal and Spatial dynamics in the phytomacrofaunal community of Lake Henley, New Zealand. New Zealand Journal of Marine and Freshwater research 31:423-434.

Newman, RM. (1991). Herbivory and detrivory on freshwater macrophytes by invertebrates. In: A Review. J.N. Benthol. Soc. 10(2): 89 - 114.
Saliu, JK. Jr. (1989). Aquatic insects associated with plants in two reservoirs at Ibadan, Nigeria. Revista de Biologia Tropical, 37:217-219.

Sloey, D; Schenck, T; Narf, R. (1997). Distribution of aquatic invertebrates within a dense bed of Eurasian milfoil (Myriophyllum spicatum L.). Journal of Freshwater Ecology 12: 303-313.

Sokal, RR; Rohlf, FJ. (1981). Biometry. WH Freeman and Co. San Francisco. USA.

Smock, LA; Stoneburner, DL. (1980). The response of macroinvertebrates to aquatic macrophyte decomposition. Oikos, 35:397-403.

Tokeshi, M; Pinder, LVC. (1985). Microhabitats of stream invertebrates on two submersed macrophytes with contrasting leaf morphology. Holartic Ecology 8: 313-319.

Uwadiae, RE. (2009). An ecological study on the macrobenthic invertebrate community of Epe lagoon, Lagos. PhD. Thesis University of Lagos, Akoka, Lagos.

Uwadaiae RE; Okunade GO.; Okosun AO. (2011). Community structure, biomass and density of benthic phytomacrofauna communities in a tropical lagoon infested by water hyacinth (Eichhornia crassipes). Pan-American Journal of Aquatic Sciences, 6(1):44-56.

Williams, C.B. 1943. Area and number of species. Nature 152: 264-267.

Yankson K.; Kendall MA. (2001). Student's guide to the seashore of West Africa. Marine Biodiversity Capacity Building in the West African Subregion. Darwin Initiative Report 1, Ref. $162 / 7 / 451$. 